\title{
Foodborne and waterborne illness among Canadian Indigenous populations: A scoping review
}

\author{
JKH Jung ${ }^{1}$, K Skinner ${ }^{1 *}$
}

\section{Abstract}

Background: Indigenous populations are often at higher risk for foodborne illness than the general Canadian population.

Objective: To investigate the extent of the literature on the link between food safety and the occurrence of foodborne and waterborne illness in Canadian Indigenous populations.

Methods: A scoping review was conducted using search strings in five databases and grey literature to identify all papers that studied a Canadian Indigenous population and referred to any potential associations between food safety (including consumption and preparation of traditional foods and retail foods) or water safety practices and food or waterborne illness. Two authors screened papers based on inclusion and exclusion criteria. Included documents were analyzed for emergent themes.

Results: From 1,718 unique records identified, 21 documents were selected. Foodborne illness was most common in children up to 14 years old. Walrus, seal, caribou and whale were the most common traditional foods tied to foodborne illness and were primarily associated with botulism and trichinosis. Aside from consuming the food raw, fermentation was the most common traditional food preparation method linked to foodborne illness. There was concern about the safety of retail food but no clear link was identified with foodborne illness. Lastly, although there was concern about tap water, the use of alternate water sources, such as untreated brook water, and hygiene and cleaning practices in communities with boil water advisories were the most common risk behaviours associated with waterborne illness.

Conclusion: Consumption of certain game meats, as well as the use of traditional fermentation practices may lead to an increased risk of foodborne illness among Indigenous populations. Concern about tap water may lead to use of unsafe alternate water sources. Further research is needed to examine potential culturally appropriate food and water safety opportunities.

\section{Affiliation}

${ }^{1}$ School of Public Health and Health Systems, University of Waterloo, Waterloo, ON

*Correspondence: kskinner@ uwaterloo.ca

Suggested citation: Jung JKH, Skinner K. Foodborne and waterborne illness among Canadian Indigenous populations: A scoping review. Can Commun Dis Rep. 2017;43(1):7-13. https://doi.org/10.14745/ ccdr.v43i01a02

\section{Introduction}

Foodborne and waterborne illness are important public health issues worldwide, with morbidity and mortality affecting both developed and developing countries $(1,2)$. Primarily caused by bacteria, viruses and parasites, foodborne illness and waterborne illness typically present in the form of gastrointestinal symptoms $(3,4)$. In Canada, it is estimated that foodborne illness affects about one in eight Canadians (four million cases) each year (3). However, the burden of foodborne illness is not distributed equally, as the risk of enteric illness is believed to be higher in many Indigenous communities compared to the national average (5). Likewise, these communities also face increased risk of waterborne illnesses, particularly due to environmental factors (6).

There are several reasons for the higher risk of foodborne and waterborne illness in Indigenous communities. A large proportion of Indigenous people are included in the groups at most risk: infants, young children, pregnant women and the elderly (7). However, another reason for the higher prevalence can be linked to preparation methods and consumption of traditional foods. For example, the consumption of meat-such as seal, whale, walrus and caribou-in raw form is common among some Indigenous groups, which poses a health risk from pathogens normally destroyed by proper cooking (7). Non-adherence to boil water advisories in Canadian Indigenous communities can also affect the risk of contracting waterborne illness $(5,8,9)$.

To our knowledge, a comprehensive review of foodborne and waterborne illness among Canadian Indigenous populations caused by food and water safety practices has not been conducted. Thus, a scoping review was performed because it is most useful when no comprehensive review exists. The objective of this scoping review was to investigate the extent, nature and range of studies on the link between food safety and occurrence of foodborne and waterborne illness in Canadian Indigenous populations. 


\section{Methods}

This scoping review followed the five-step framework developed by Arksey and O'Malley (10). First we established the research question: "What is currently known about the connection between food safety and occurrence of foodborne/waterborne illness in the Canadian Indigenous population?" Food safety was defined as the handling, preparation and storage of food to preserve the quality of the food and prevent contamination (11) and also included the preparation and consumption of traditional foods. Traditional foods are those obtained from local plant or animal sources through gathering or harvesting, possess cultural meaning (12) and are generally synonymous with the terms "wild food" and "country food". We included the risk for waterborne illness if it was related to individual/community behavioural practices and not solely due to environmental contamination. We considered all forms of disease caused by contaminated food or water sources, and not merely those related to acute gastrointestinal illness (for example, we included hepatitis $A$ in our search). We chose the term "Indigenous" to refer collectively to First Nations, Métis and Inuit peoples. However groups were also reported in the way they were described in the studies.

\section{Study identification}

A research librarian guided the development of relevant search strings for five academic databases (Appendix). Due to the broad definition of food safety, this term was not included in the search strategy, but was used as part of the inclusion and exclusion criteria when screening (Text box). Journals (not indexed in the databases) and publications by a selection of authors who study food consumption among Indigenous populations were also hand searched (Appendix). All returned citations were exported into RefWorks@.

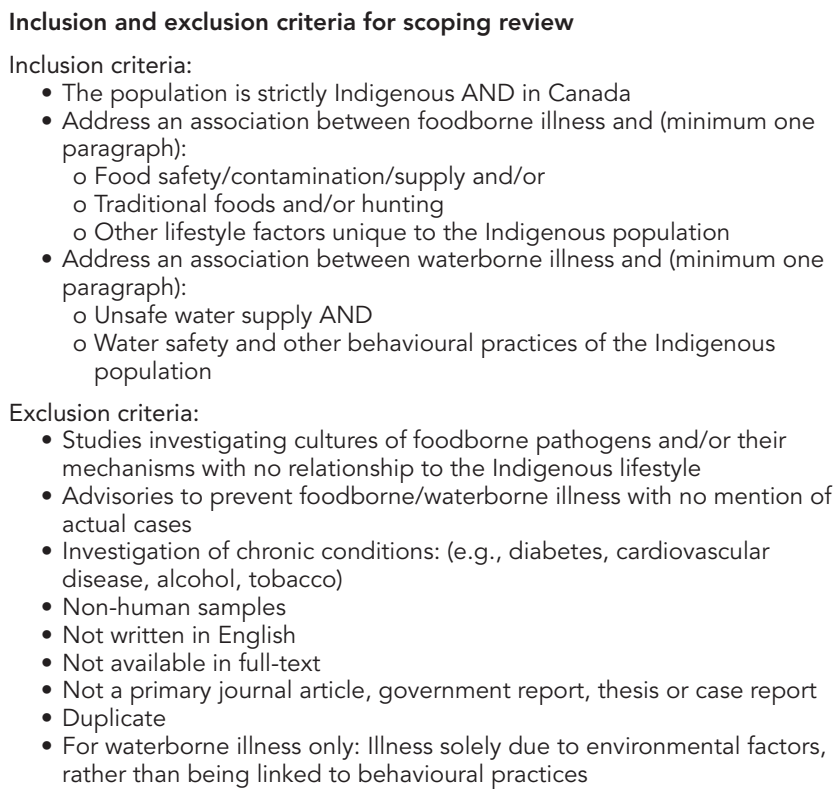

A custom Google search engine that captured the websites of Canada's federal and provincial health departments and public health agencies was used to access grey literature $(13,14)$. A dissertation and thesis database was also used as well as three federal government websites (Appendix). For the grey literature search, several searches were conducted using different combinations of key terms instead of one systematic search string (12; Appendix).

\section{Study selection}

Titles and abstracts of all returned citations were screened based on a priori inclusion/exclusion criteria. Two independent reviewers scanned the full-text documents using the criteria for final inclusion. Conflicts were discussed between reviewers and the criteria was revisited until an agreement could be reached. Cohen's Kappa (k) was used to assess inter-rater agreement between the reviewers, where $k=0.7$ was considered sufficient. There was no limit on the year of publication. For duplicate documents from the same study (multiple publications based on the same data) or report (revised version of previous year's report), the document with the most relevant information was chosen.

\section{Data collection, analysis and reporting}

Information collected from each document included: author(s), publication year, location of study in Canada, specific Indigenous population, type of document, study objective, number of cases, type of illness addressed, specific pathogen addressed and reported main health outcomes. Results were summarized through qualitative thematic analysis and emerging themes. Demographic variables such as age, sex and community-level factors were explored for potential connections to foodborne and waterborne illness. Specific types of traditional foods consumed by those who became ill, as well as preparation methods linked to illness were reported. The role of retail food (or purchased food) in Indigenous communities that may lead to increased risk for illnesses was examined, and any water safety practices in connection to waterborne illness were recorded. As with most scoping reviews, a formal quality assessment of the studies was not conducted (9).

\section{Results}

From the 1,718 unique records identified through databases, hand-searches and grey literature, 21 documents (20 journal articles and one report) were included for the qualitative analysis (Figure 1). Reasons for exclusion are noted in Figure 1. There was reasonably strong agreement between reviewers at the full-article screening level $(k=0.75)$.

\section{Demographic and social factors}

Of the 21 documents reviewed, eight (38\%) reported trends between age and the occurrence of foodborne and waterborne illness $(7,8,19,25,28-31)$. Of these, six $(75 \%)$ noted higher prevalence in children up to 14 years old $(7,19,28-31)$, One study did not report any difference due to age (8) and one showed that most of the trichinosis cases were in those over 60 years old and were more likely to be female (25). Of the six documents that reported some form of trend by male/female gender, half noted approximately equal distribution for botulism (16), E. coli (28) and hepatitis $A(30,31)$. Overcrowding in homes was noted in four articles, particularly during winter $(5,29,30,31)$. Two studies $(8,29)$ reported that tight social networks in small remote communities may be another possible mode of transmission for foodborne illness. One document (7) identified the practice of sharing food among family and community members, after a hunt or harvest, as a potential vehicle for foodborne illness transmission. 


\section{Figure 1: Flow diagram of screening process}

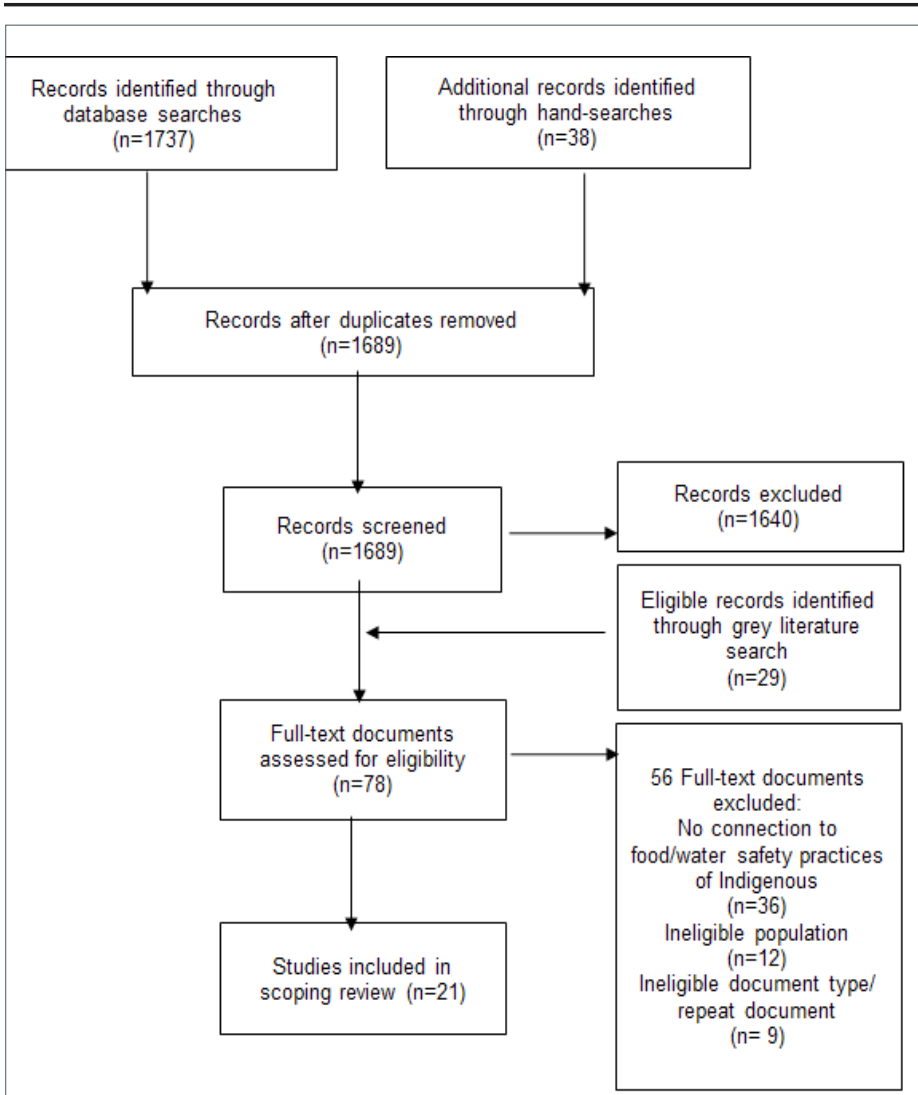

\section{Foodborne illness}

There were 16 studies on foodborne illness (Table 1). Of these, $15(94 \%)$ were in Inuit populations, and the next most common was First Nations of British Columbia. The most common place of study was in the Northwest Territories (50\%); Nunavut, British Columbia, Quebec, Ontario, and Manitoba were other places studied.

Type of traditional foods and traditional preparation methods The main themes addressed by the studies are listed in Figure 2. Of the 18 relevant studies, walrus (44\%), seal (39\%), caribou $(39 \%)$ and whale $(33 \%)$ were the most commonly mentioned traditional foods tied to foodborne illness, especially when eaten raw. Other traditional foods linked to illness included fermented salmon eggs (stink eggs) $(7,16,21-23)$ and fish (such as char, salmon and trout $(5,7,21)$. Aside from raw meat consumption, the fermentation of traditional foods was the most common traditional preparation method involved in foodborne illness $(7,16,20-23,25,26)$. This was most commonly linked with seal $(7,20-23)$, walrus $(7,20,25,26)$ and stink eggs $(7,16,19,20)$. It was noted that the fermentation methods used by the First Nations and Inuit do not produce lactic acid, acetic acid, or ethanol to inhibit the growth of pathogens (7). Traditional Indigenous fermentation methods have been noted as more of a decomposition or putrefaction process and the low $\mathrm{pH}$ required to inhibit the growth of pathogens may not be achieved (21).
Table 1: Canadian studies on foodborne illness in Indigenous populations

\begin{tabular}{|c|c|}
\hline $\begin{array}{l}\text { Population and } \\
\text { location (Ref.) }\end{array}$ & $\begin{array}{l}\text { Study objective } \\
\text { (cases) }\end{array}$ \\
\hline $\begin{array}{l}\text { Inuit in Labrador and } \\
\text { Nunavut }(5)^{1}\end{array}$ & $\begin{array}{l}\text { To estimate the burden of community-level } \\
\text { self-reported acute gastrointestinal illness in Inuit } \\
\text { communities of Rigolet, Labrador }(n=30) \text { and } \\
\text { lqaluit, Nunavut ( } n=72)\end{array}$ \\
\hline $\begin{array}{l}\text { Inuit, First Nations, Métis } \\
\text { across Canada (7) }\end{array}$ & $\begin{array}{l}\text { To identify food safety issues associated with } \\
\text { traditional/country foods and environmental } \\
\text { factors, and to assess the effectiveness of programs } \\
\text { aimed at decreasing the number of foodborne } \\
\text { illnesses }\end{array}$ \\
\hline Inuit in Labrador $(8)^{1}$ & $\begin{array}{l}\text { To understand the lived experience of acute } \\
\text { gastrointestinal illness in a small Inuit community of } \\
\text { Rigolet, Canada }(n=30)\end{array}$ \\
\hline $\begin{array}{l}\text { First Nations in MB and } \\
\text { Inuit in NWT (9) }\end{array}$ & $\begin{array}{l}\text { To examine causes of diarrhea in Winnipeg and } \\
\text { Berens River, Manitoba and Eskimo Point, NWT } \\
(n=172)\end{array}$ \\
\hline $\begin{array}{l}\text { Inuk in Inuvialuit, } \\
\text { NWT(15) }\end{array}$ & $\begin{array}{l}\text { To identify the cause of botulism of a } 58 \text {-year-old } \\
\text { Inuvialuit woman }(n=1)\end{array}$ \\
\hline $\begin{array}{l}\text { Inuit in Nunavik, } \mathrm{QC} \text { and } \\
\text { First Nations across BC } \\
(16)\end{array}$ & $\begin{array}{l}\text { To summarize botulism cases in Canada from } 1985 \\
\text { to } 2005(n=205)\end{array}$ \\
\hline $\begin{array}{l}\text { Inuit, First Nations, and } \\
\text { Métis across NWT (17) }\end{array}$ & $\begin{array}{l}\text { To examine community-level risk factors for } \\
\text { notifiable gastrointestinal illnesses in Northwest } \\
\text { Territories }(n=708)\end{array}$ \\
\hline Inuit in Nunavik, QC (18) & $\begin{array}{l}\text { To review the effectiveness of the Nunavik } \\
\text { Trichinellosis Prevention Program }(n=95)\end{array}$ \\
\hline Inuit in Nunavut (19) & $\begin{array}{l}\text { To describe brucellosis cases and the } \\
\text { bacteriological investigation of the organisms } \\
\text { isolated ( } n=7)\end{array}$ \\
\hline Inuit in Nunavik, QC (20) & $\begin{array}{l}\text { To summarize four unrelated outbreaks of botulism } \\
\text { in Ungava Bay, Nunavik, Quebec }(n=9)\end{array}$ \\
\hline $\begin{array}{l}\text { Mainly Inuit across QC, } \\
\text { NWT and BC (21) }\end{array}$ & $\begin{array}{l}\text { To summarize botulism cases in Canada from } 1971 \\
\text { to } 1984(n=113)\end{array}$ \\
\hline $\begin{array}{l}\text { First Nations of BC and } \\
\text { ON and Inuit, across QC } \\
\text { and NWT (22) }\end{array}$ & $\begin{array}{l}\text { To summarize botulism cases in Canada from } 1971 \\
\text { to } 1974(n=42)\end{array}$ \\
\hline $\begin{array}{l}\text { First Nations of BC and } \\
\text { ON and Inuit across } \mathrm{QC} \\
\text { and NWT (23) }\end{array}$ & $\begin{array}{l}\text { To summarize botulism cases in Canada from } 1919 \\
\text { to } 1973(n=122)\end{array}$ \\
\hline $\begin{array}{l}\text { Inuit in Nunavut and QC } \\
(24)\end{array}$ & $\begin{array}{l}\text { To present three outbreaks of botulism in Cape } \\
\text { Dorset and Frobisher Bay, Nunavut; and Wakeham } \\
\text { Bay, Quebec among Eskimos during 1967-1969 } \\
(n=9)\end{array}$ \\
\hline Inuit in Nunavut (25) & $\begin{array}{l}\text { To describe an outbreak of trichinellosis on Baffin } \\
\text { Island, August-September } 1999(n=34)\end{array}$ \\
\hline Inuit in $\mathrm{QC}(26)$ & $\begin{array}{l}\text { To describe an outbreak of trichinosis after the } \\
\text { consumption of raw walrus meat in } 10 \text { Inuit } \\
\text { inhabitants of Saluit, Quebec. }(n=10)\end{array}$ \\
\hline Inuit in NWT (27) & $\begin{array}{l}\text { To examine the cause of brucellosis in a nine year } \\
\text { old Inuit boy }(n=1)\end{array}$ \\
\hline Inuit in NWT (28) & $\begin{array}{l}\text { To describe the clinical and epidemiologic features } \\
\text { of an outbreak of verotoxin-producing Escherichia } \\
\text { coli associated diarrhea in Keewatin, NWT }(n=152)\end{array}$ \\
\hline Inuit in NWT (29) & $\begin{array}{l}\text { To evaluate risk factors for childhood } \\
\text { hemolytic-uremic syndrome and gastroenteritis } \\
\text { during an epidemic of E. coli O157:H7 infection in } \\
\text { Arviat, Nunavut ( } n=84)\end{array}$ \\
\hline First Nations of BC $(30)^{2}$ & $\begin{array}{l}\text { To determine if hepatitis } A \text { incidence is higher in } \\
\text { Aboriginal people than total BC population and if } \\
\text { this is associated with poverty and unsanitary living } \\
\text { conditions }(n=2,933)\end{array}$ \\
\hline $\begin{array}{l}\text { First Nations of Northern } \\
\mathrm{BC}(31)^{2}\end{array}$ & $\begin{array}{l}\text { To describe the outbreak of hepatitis } A \text { in the } \\
\text { Northern Interior Health Region of } B C \text { and the } \\
\text { public health response }(n=23)\end{array}$ \\
\hline
\end{tabular}


Figure 2: Themes related to food and water safety identified from included studies $(n=21)$

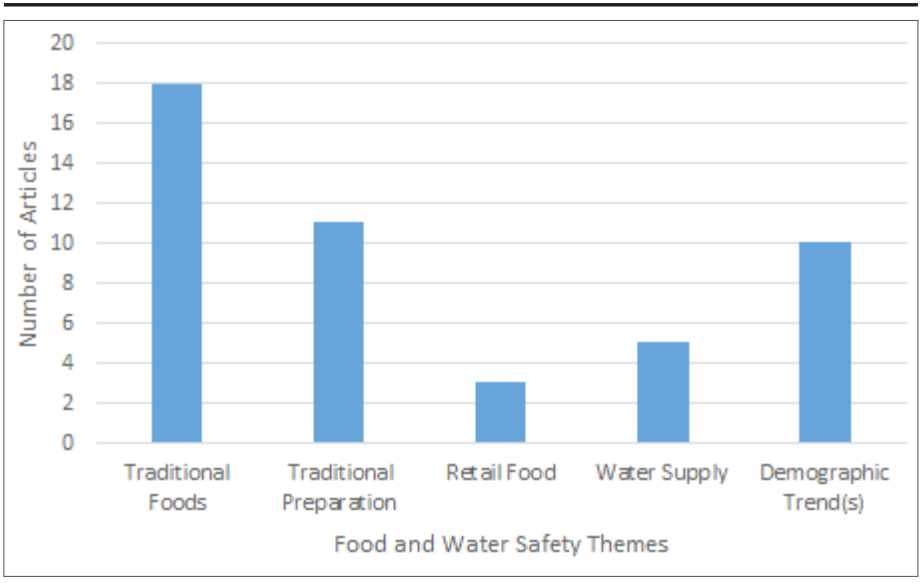

\section{Types of infection}

The most common types of infection reported are noted in Figure 3. Almost one third of the articles $(n=7)$ discussed botulism $(15,16,20,24)$. Trichinosis was discussed in almost $15 \%$ of studies. Brucellosis, E. coli and hepatitis A were identified in about $10 \%$ of studies. Brucellosis, was specifically linked with the consumption of caribou $(19,27)$ populations.

Figure 3: Common sources of gastrointestinal illness identified in included studies $(n=21)$

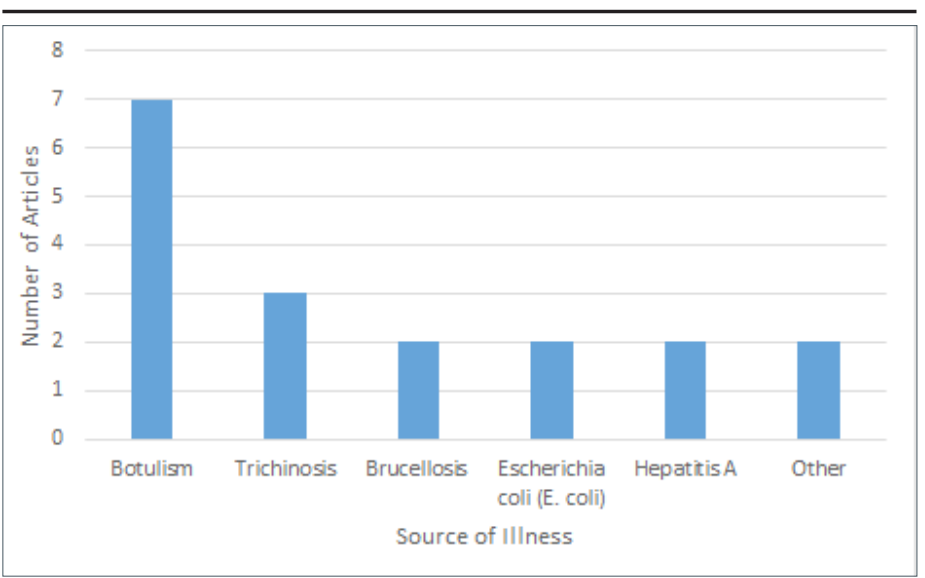

\section{Retail food}

In a review of food safety and Aboriginal traditional foods, some studies showed Indigenous people were concerned about the safety of retail food but few assessed the correlation between retail food and foodborne illness in Indigenous populations (7). One study suggested that retail food could have been a factor for acute gastrointestinal illness in an Inuit community (8) and another found the odds of developing acute gastrointestinal illness were increased if the person responsible for food preparation was employed (5). The authors suggested that those with higher income may have less time to access country food and instead consumed more retail food, but this was not confirmed. Conversely, a study in the Northwest Territories (17) found the higher the food prices in native communities, the lower the risk was for campylobacteriosis. The authors proposed that the higher food prices may lead to lower consumption of retail meat, dairy and fruits and vegetables and choosing processed items, which could reduce exposure to pathogens more commonly observed in perishable foods.

\section{Waterborne illness}

Table 1 identifies that about one-quarter of all studies addressed unsafe water practices in Indigenous communities associated with either water or foodborne illness $(5,7,8,30,32)$. Three documents $(5,7,8)$ mentioned the preference of Indigenous communities to drink alternative water sources such as bottled water and untreated brook water rather than tap water. One article (8) mentioned how Inuit members in Rigolet, Labrador, perceived tap water to be a potential risk factor for acute gastrointestinal illness, while viewing untreated brook water to be safe. However, in a similar study (5), which included the same members of Rigolet, the consumption of these tap water alternatives was associated with developing acute gastrointestinal illness. There was also concern regarding non-compliance to boil water advisories, a potential contributing factor to developing waterborne illness in two studies $(8,31)$. Lastly, one article (30) noted how community water supply problems (which led to higher incidence of hepatitis $A$ in this study) may also lead to infrequent hand-washing or inadequate cleaning as the water quality may be viewed as unreliable. In turn, that can serve as a further disease vector.

\section{Discussion}

This article provides the most up-to-date review of studies on food safety and unsafe water practices in Indigenous populations in Canada leading to foodborne and waterborne illness. Most studies reported that foodborne illnesses occurred primarily in children up to 14 years of age and females, and that overcrowded housing and food sharing may be potential vehicles for transmission of illness. Walrus, seal, caribou and whale-especially when eaten raw or were fermented by processes that do not inhibit the growth of pathogens-were associated with an increased risk for foodborne illness.

There are several limitations to consider when reviewing these results. First, the review identified only 21 studies conducted over the last 50 years. Error and bias could have been introduced during the screening process, with some articles being missed or incorrectly included/excluded in the review. Additionally, the search was limited to documents in the English language. We identified studies that reported the belief that retail food consumption was linked to foodborne illness but there is currently no evidence for this, therefore it deserves further study. Likewise, a fear of tap water was reported and although this has been a problem in some Indigenous communities (32), it is uncertain whether it is linked with illness in all communities. It appears the risk of drinking untreated brook water may be underestimated which deserves further study.

\section{Future research}

Overall, Indigenous populations in Canada face unique sources of infections due to environmental and social factors. More research is needed to better understand these issues and whether different public health approaches may be needed for effective prevention. When researching ways to decrease foodborne illness and unsafe water practices in Indigenous communities, cultural implications should be considered. For example, it is important to acknowledge that although foodborne illness may be linked to the consumption of traditional foods, these foods also have many health benefits and are essential to wellbeing. The preparation and consumption of traditional foods help to reinforce Indigenous culture and identity (33) and contribute to the total diet, as they are rich in 
iron, zinc and protein (34). Likewise, although food sharing was associated with foodborne infections, Indigenous populations value social connectedness which brings many benefits to their health, well-being, spirituality and community spirit. All these factors should be carefully considered when developing food safety guidance. Programs are more likely to be effective if they are designed with community input and respect for Indigenous knowledge systems and cultural food ways (7). For example, the government of Nunavut has been developing guidelines for food safety when serving country food in government-funded facilities and community programs (35). These guidelines could be considered and applied in other contexts.

The influence of climate change on foodborne illnesses in Indigenous communities and its impact on the health care system merits further examination. This is particularly relevant as higher temperatures may result in increasing temperature-sensitive foodborne illnesses such as botulism $(7,36)$ which in turn may result in significant financial costs to the health care system.

\section{Conclusion}

There is limited research that examines the unique food safety and water safety challenges that Indigenous populations in Canada face that may be associated with their environment, traditional foods, and food preparation techniques as well as social and cultural beliefs and practices. It appears that consumption of certain game meats, as well as the use of traditional fermentation practices, may lead to increased risk for foodborne illness among the Indigenous population. Further research is needed to inform culturally appropriate food safety practices.

\section{Acknowledgements}

The authors would like to thank Jackie Stapleton, the academic librarian for the School of Public Health and Health Systems at the University of Waterloo, for assisting them in the development of search strings and establishment of proper screening methodology.

\section{Conflict of interest}

None.

\section{Funding}

None.

\section{References}

1. Newell DG, Koopmans M, Verhoef L, Duizer E, Aidara-Kane A, Sprong $\mathrm{H}$, et al. Foodborne diseases: The challenges of 20 years ago still persist while new ones continue to emerge. Int J Food Microbiol. 2010;139 Suppl 1:S3-15.

2. Thomas MK, Majowicz SE, Pollari F, Sockett PN. Burden of acute gastrointestinal illness in Canada, 1999-2007: Interim summary of NSAGI activities. Can Commun Dis Rep. 2008
May;34(5):8-15. Available from: http://www.phac-aspc.gc.ca/ publicat/ccdr-rmtc/08vol34/dr-rm3405b-eng.php.

3. Thomas MK, Murray R, Flockhart L, Pintar K, Pollari F, Fazil A, et al. Estimates of the burden of foodborne illness in Canada for 30 specified pathogens and unspecified agents, circa 2006. Foodborne Pathog Dis. 2013;10(7):639-48.

4. Public Health Agency of Canada. The Chief Public Health Officer's report on the state of public health in Canada, 2013: Infectious disease - the never-ending threat. Ottawa: PHAC; 2013 [Internet] [cited 2016 Sept 20]. Available from: http://www.phac-aspc.gc.ca/cphorsphc-respcacsp/2013/ food-water_alim-eau-eng.php.

5. Harper SL, Edge VL, Ford J, Thomas MK, Pearl DL, Shirley J, et al. Acute gastrointestinal illness in two Inuit communities: Burden of illness in Rigolet and Iqaluit, Canada. Epidemiol Infect. 2015;143(14):3048-63.

6. Harper SL, Edge VL, Schuster-Wallace CJ, Berke O, McEwen SA. Weather, water quality and infectious gastrointestinal illness in two Inuit communities in Nunatsiavut, Canada: Potential implications for climate change. Ecohealth. 2011;8(1):93-108.

7. Food Safety Network. Safe preparation and storage of Aboriginal traditional/country foods: A review. Aston Manor SA: Food Safety Network; 2009.

8. Harper SL, Edge VL, Ford J, Thomas MK, IHACC Research Group, Rigolet Inuit Community Government, et al. Lived experience of acute gastrointestinal illness in Rigolet, Nunatsiavut: "just suffer through it". Soc Sci Med. 2015;126:86-98.

9. Gurwith M, Wenman W, Gurwith D, Brunton J, Feltham S, Greenberg $\mathrm{H}$. Diarrhea among infants and young children in Canada: A longitudinal study in three northern communities. J Infect Dis. 1983;147(4):685-92.

10. Arksey H, O'Malley L. Scoping studies: Towards a methodological framework. Int J Soc Res Methodol. 2005;8(1):19-32.

11. University of Maryland Medical Center [Internet]. Food safety. Baltimore MD: University of Maryland; 2014 [updated 2016; cited 2016 Jun 13]. Available from: http://umm.edu/ health/medical/ency/articles/food-safety.

12. Willows ND. Determinants of healthy eating in Aboriginal peoples in Canada: The current state of knowledge and research gaps. Can J Public Health. 2005;96 Suppl 3:S32-6, S36-41.

13. Godin K, Stapleton J, Kirkpatrick SI, Hanning RM, Leatherdale ST. Applying systematic review search methods to the grey literature: A case study examining guidelines for school-based breakfast programs in Canada. Syst Rev. 2015;4:138.

14. Ontario Public Health Libraries Association [Internet]. Custom search engine for Canadian public health information. 2016 [Cited 2016 Jun 8]. Available from: http://www.ophla.ca/customsearchcanada.htm.

15. Kraft C, Wuerz T, Cram J, Seaman L. Botulism presenting as dyspnea and respiratory failure in the Canadian Arctic. CMAJ. 2016;188(12):896-8. 
16. Leclair D, Fung J, Isaac-Renton JL, Proulx JF, May-Hadford $\mathrm{J}$, Ellis A, et al. Foodborne botulism in Canada, 1985-2005. Emerg Infect Dis. 2013;19(6):961-8.

17. Pardhan-Ali A, Wilson J, Edge VL, Furgal C, Reid-Smith R, Santos $\mathrm{M}$, et al. Community-level risk factors for notifiable gastrointestinal illness in the Northwest Territories, Canada, 1991-2008. BMC Public Health. 2013;13:63.

18. Larrat S, Simard M, Lair S, Belanger D, Proulx JF. From science to action and from action to science: The Nunavik Trichinellosis Prevention Program. Int J Circumpolar Health. $2012 ; 71$.

19. Toshach S. Brucellosis in the Canadian Arctic. Can J Public Health. 1963;54:271-5.

20. Proulx JF, Milor-Roy V, Austin J. Four outbreaks of botulism in Ungava Bay, Nunavik, Quebec. Can Comm Dis Rep [Internet]. 1997;23(4):30-2. Available from: http://www. collectionscanada.gc.ca/webarchives/20071125115222/ http://www.phac-aspc.gc.ca/publicat/ccdr-rmtc/97vol23/ dr2304ed.html.

21. Hauschild AH, Gauvreau L. Foodborne botulism in Canada, 1971-84. CMAJ. 1985;133(11):1141-6.

22. Bowmer FJ, Wilkinson DA. Botulism in Canada, 1971-74. Can Med Assoc J. 1976;115(11):1084-6.

23. Dolman CE. Human botulism in Canada (1919-1973). Can Med Assoc J. 1974;110(2):191-7 passim.

24. Stuart PF, Wiebe EJ, McElroy R, Cameron DG, Todd EC, Erdman IE, et al. Botulism among Cape Dorset Eskimos and suspected botulism at Frobicher Bay and Wakeham Bay. Can J Public Health. 1970;61(6):509-17.

25. Serhir B, MacLean JD, Healey S, Segal B, Forbes L. Outbreak of trichinellosis associated with arctic walruses in northern Canada, 1999. Can Comm Dis Rep [Internet]. 2001;27(4):31-6. Available from: http://www. collectionscanada.gc.ca/webarchives/20071214025400/ http://www.phac-aspc.gc.ca/publicat/ccdr-rmtc/01vol27/ dr2704eb.html.

26. Viallet J, MacLean JD, Goresky CA, Staudt M, Routhier G, Law C. Arctic trichinosis presenting as prolonged diarrhea. Gastroenterology. 1986;91(4):938-46.

27. Chan J, Baxter C, Wenman WM. Brucellosis in an Inuit child, probably related to caribou meat consumption. Scand J Infect Dis. 1989;21(3):337-8.
28. Orr P, Lorencz B, Brown R, Kielly R, Tan B, Holton D, et al. An outbreak of diarrhea due to verotoxin-producing Escherichia coli in the Canadian Northwest Territories. Scand J Infect Dis. 1994;26(6):675-84.

29. Rowe PC, Orrbine E, Ogborn M, Wells GA, Winther W, Lior $\mathrm{H}$, et al. Epidemic Escherichia coli O157:H7 gastroenteritis and hemolytic-uremic syndrome in a Canadian Inuit community: Intestinal illness in family members as a risk factor. J Pediatr. 1994;124(1):21-6.

30. Jin A, Martin JD. Hepatitis A among residents of First Nations Reserves in British Columbia, 1991-1996. Can J Public Health. 2003;94(3):176-9.

31. Harb J, Lem M, Fyfe M, Patrick D, Ochnio J, Dobson S, et al. Hepatitis $A$ in the northern interior of British Columbia: An outbreak among members of a First Nations community. Can Comm Dis Rep [Internet]. 2000;26(19):157-61. Available from: http://www.collectionscanada.gc.ca/ webarchives/20071220063654/http://www.phac-aspc.gc.ca/ publicat/ccdr-rmtc/00vol26/dr2619ea.html.

32. Health Canada [Internet]. Drinking water and waste water. Ottawa: Health Canada; 2016 [updated 2016 Sep 28; cited 2016 Jul 20]. Available from: http://www.hc-sc.gc.ca/fniahspnia/promotion/public-publique/water-eau-eng.php.

33. Damman S, Eide WB, Kuhnlein HV. Indigenous peoples' nutrition transition in a right to food perspective. Food Policy. 2008;33(2):135-55.

34. Kuhnlein HV, Receveur O. Local cultural animal food contributes high levels of nutrients for Arctic Canadian Indigenous adults and children. J Nutr. 2007;137(4):1110-4.

35. Government of Nunavut. Serving country food in government-funded facilities and community programs. 2016. Available from: http://www.nunavutfoodsecurity.ca/ sites/default/files/news/Serving\%20country\%20food.pdf.

36. Parkinson AJ, Butler JC. Potential impacts of climate change on infectious diseases in the Arctic. Int J Circumpolar Health. 2005;64:478-86. 


\section{Appendix: Databases used and search strategy}

\section{Databases Used:}

1. PubMed

2. Scopus

3. Cumulative Index of Nursing and Allied Health Literature (CINAHL)

4. Bibliography of Native North Americans

5. Sociological Abstracts

\section{Database Example - PubMed Search Terms:}

(gastrointestinal disease*[tw] OR gastrointestinal illness*[tw] OR gastroenteritis[tw] OR intestinal disease*[tw] OR enteric disease*[tw] OR enteritis[tw] OR enterocolitis[tw] OR foodborne disease*[tw] OR foodborne illness*[tw] OR food poisoning[tw] OR waterborne disease*[tw] OR waterborne illness*[tw] OR diarrhea[tw] OR dysentery[tw] OR amebiasis[tw] OR botulism[tw] OR brucellosis[tw] OR campylobacter[tw] OR cholera[tw] OR cryptosporidiosis[tw] OR cyclosporiasis[tw] OR giardiasis[tw] OR hepatitis $A[t w]$ OR legionellosis[tw] OR listeriosis[tw] OR shellfish poisoning[tw] OR salmonella infection*[tw] OR salmonellosis[tw] OR shigellosis[tw] OR trichinellosis[tw] OR trichinosis[tw] OR escherichia coli[tw] OR yersinia infection*[tw] OR yersiniosis[tw] OR typhoid fever[tw] OR paratyphoid fever[tw] OR

gastrointestinal diseases[MeSH:noexp] OR gastroenteritis[MeSH] OR intestinal diseases[MeSH:noexp] OR enteritis[MeSH]

OR enterocolitis[MeSH] OR foodborne diseases[MeSH] OR diarrhea[MeSH] OR dysentery[MeSH] OR amebiasis[MeSH] OR brucellosis[MeSH] OR campylobacter[MeSH:noexp] OR cholera[MeSH] OR cryptosporidiosis[MeSH] OR cyclosporiasis[MeSH] OR giardiasis[MeSH] OR hepatitis A[MeSH] OR legionellosis[MeSH] OR listeriosis[MeSH] OR salmonella infections[MeSH] OR trichinellosis[MeSH] OR escherichia coli[MeSH] OR yersinia infections[MeSH]) AND ((inuit[tw] OR rigolet[tw] OR "first nations"[tw] OR metis[tw] OR cree[tw] OR ojibway[tw] OR oji cree[tw] OR nunavut[tw] OR yukon[tw] OR "northwest territories"[tw] OR "northern ontario"[tw] OR arctic[tw] OR subarctic[tw] OR inuits[MeSH] OR nunavut[MeSH] OR yukon[MeSH] OR "northwest territories"[MeSH])) OR ((Canada[tw] OR Canadian[tw] OR Canada[MeSH]) AND (aborgin*[tw] OR indigen*[tw] OR native[tw] OR natives[tw])))

\section{Grey Literature Database and Websites Used:}

1. A custom Google search engine (captures websites of Canada's federal and provincial health departments and public health agencies)

2. ProQuest Dissertations and Thesis Global Database

3. Federal Government Websites

a. Health Canada

b. Public Health Agency of Canada

c. Canadian Food Inspection Agency

\section{Grey Literature Search Terms}

Search 1. Foodborne illness AND Aboriginals OR First Nations

Search 2. Foodborne disease AND Aboriginals OR First Nations

Search 3. Waterborne disease AND Aboriginals OR First Nations

Search 4. Waterborne illness AND Aboriginals OR First Nations

Search 5. Gastrointestinal illness AND Aboriginals OR First Nations

Search 6. Diarrhea AND Aboriginals OR First Nations

Search 7. Food safety AND Aboriginals OR First Nations

Search 8. Food poisoning AND Aboriginals OR First Nations

*The eight search strategies were applied to each search engine with up to 50 records being screened for each search (totalling to 400 records per search engine). 